Louisiana State University

LSU Digital Commons

9-1-2016

\title{
Biological control of invasive Phragmites australis will be detrimental to native $P$. australis
}

James T. Cronin

Louisiana State University

Erik Kiviat

Hudsonia Ltd

Laura A. Meyerson

University of Rhode Island

Ganesh P. Bhattarai

University of Florida Institute of Food and Agricultural Sciences

Warwick J. Allen

Louisiana State University

Follow this and additional works at: https://digitalcommons.Isu.edu/biosci_pubs

\section{Recommended Citation}

Cronin, J., Kiviat, E., Meyerson, L., Bhattarai, G., \& Allen, W. (2016). Biological control of invasive Phragmites australis will be detrimental to native P. australis. Biological Invasions, 18 (9), 2749-2752. https://doi.org/10.1007/s10530-016-1138-x 


\title{
Biological control of invasive Phragmites australis will be detrimental to native $P$. australis
}

\author{
James T. Cronin - Erik Kiviat • \\ Laura A. Meyerson - Ganesh P. Bhattarai • \\ Warwick J. Allen
}

Received: 31 March 2016/Accepted: 3 April 2016/Published online: 13 April 2016

(C) Springer International Publishing Switzerland 2016

Keywords Phragmites australis - Biological control · Local enemy release

European Phragmites australis is widespread as a nonnative genotype in North America, abundant in many places, and often considered a pest. There is also a much less common North American native genotype of $P$. australis, and a "Gulf Coast" genotype (Saltonstall et al. 2004). The genetics of Phragmites are complex, and in North America there are hybrids between $P$. australis and other species of Phragmites

Guest editors: Laura A. Meyerson \& Kristin Saltonstall/ Phragmites invasion.

J. T. Cronin $(\varangle)$. W. J. Allen

Department of Biological Sciences, Louisiana State

University, Baton Rouge, LA 70803, USA

e-mail: jcronin@1su.edu

\section{E. Kiviat}

Hudsonia Ltd, P.O. Box 5000/, 30 Campus Road,

Annandale, NY 12504, USA

L. A. Meyerson

Natural Resources Science, University of Rhode Island,

Kingston, RI 02881, USA

G. P. Bhattarai

Indian River Research and Education Center, University of Florida, 2199 South Rock Road, Fort Pierce,

FL 34945-3138, USA as well as between the European and North American native genotypes of $P$. australis (Paul et al. 2010; Lambertini et al. 2012; Meyerson et al. 2012). $P$. australis is one of the best-studied plants globally (Hulme et al. 2013).

European $P$. australis can become highly dominant in marshes, with effects on plant communities, birds, fishes, insects, and other organisms, as well as ecosystem processes (Meyerson et al. 2000a, b; Kiviat 2013). Some of these effects are considered negative and others positive, depending upon a stakeholder's interests or management goals. Besides habitat functions, $P$. australis provides a number of non-habitat ecosystem services in both its native and introduced ranges related to its high above and belowground biomass and productivity. Among these services are formation and stabilization of tidal wetland soils for protection against sea level rise, carbon sequestration, wave attenuation, evapotranspirational cooling of the microclimate, and removal of macronutrients and trace metals from surface waters (Meyerson 2000; Meyerson et al. 1999, 2000a, b; Hershner and Havens 2008; Kiviat 2013).

A group of researchers has been developing classical biological control for European P. australis in North America (Schwarzländer and Häfliger 2000; Tewksbury et al. 2002; Häfliger et al. 2005, 2006; Blossey 2014). Currently, at least two species of European noctuid moths are being tested as potential biological control agents. The proposed biological control is intended to affect only the European $P$. 
australis (Haplotype $\mathrm{M}$ or "invasive" P. australis), and not the native P. australis (Häfliger et al. 2005; Hinz et al. 2014). A recent request for proposals released by the New York Department of Transportation (http://files.ctctcdn.com/08b78404201/13a45c325814-4869-8bb4-f2cee531dcab.pdf) is soliciting proposals for monitoring and release of potential biocontrol agents against invasive $P$. australis in New York State.

As longtime researchers on the ecology and genetics of $P$. australis in the United States, we raise important concerns about the potential outcomes and effects of classical biological control for $P$. australis in North America. Here we address several points that have attracted little discussion in the literature during the development of $P$. australis biological control agents.

1. Successful biological control of an invasive plant genotype, variety or subspecies that is sympatric with a native genotype, variety or subspecies of the same species would require an unprecedented degree of specificity of the biological control agent. There has never been a case of successful biological control at the subspecific level. Although the literature is replete with examples of differences in preference and performance between genotypes of the same plant species (e.g., Horner and Abrahamson 1992; Underwood and Rausher 2000; Kleine and Müller 2011), these differences are rarely absolute. Even if such a case existed, the evolution of increased diet breadth is a real possibility-for example, Graves and Shapiro (2003) found that $34 \%$ of California butterflies had adopted exotic host plant species into their diets (see also Jahner et al. 2011). Adopting a novel genotype of the same species into an herbivore's diet should be even more likely (Pemberton 2000). Host shifts could result in enemy-free space for the biological control agent that may enhance its impact on the novel host plant; i.e., the native $P$. australis genotypes (Holt and Lawton 1993).

For $P$. australis, the preponderance of evidence suggests that North American native and introduced herbivores perform better on, and do more damage to, native $P$. australis than European $P$. australis. According to Tewksbury et al. (2002), at least 21 species of $P$. australis herbivores have been accidentally introduced into North America, most all of which now feed on native $P$. australis. Three species of herbivores reportedly have been restricted to a single
$P$. australis genotype in a mixed-genotype marsh in New York (Blossey 2003; Saltonstall et al. 2014)_for example, Lasioptera hungarica was found only on European P. australis whereas the gall midge Calamomyia phragmitis was only found on native $P$. australis. As a cautionary tale, the stem galler Lipara pullitarsis was previously reported to occur only on European P. australis (Blossey 2003) but later found on both genotypes (Allen et al. 2015). Moreover, $L$. hungarica attacked native-invasive hybrids suggesting that a host shift to the native genotypes may be possible through these intermediate hybrids (i.e., the hybrid bridge hypothesis; Floate and Whitham 1993). In both field surveys and common-garden studies in North America, introduced mealy plum aphids (Hyalopterus pruni) and specialist gall flies (Lipara sp.) are more prevalent on native than invasive $P$. australis (Lambert and Casagrande 2007; Lambert et al. 2007; Park and Blossey 2008; Cronin et al. 2015; Allen et al. 2015). Tissue damage from the entire guild of chewing herbivores was also greater on the native genotypes (Cronin et al. 2015). Finally, experimental studies with the aphid and a generalist chewing herbivore (fall armyworm, Spodoptera frugiperda) revealed that these patterns of damage or abundance are the result of differences in performance on native and invasive $P$. australis genotypes (Bhattarai et al. in review). Complete specificity, both in the short term and long term, to invasive $P$. australis is exceedingly unlikely.

2. Spillover effects, associational susceptibility and apparent competition will likely occur and negatively impact native $P$. australis. Even if strong preferences exist for invasive $P$. australis, herbivore spillover onto native $P$. australis stands will occur, particularly at high herbivore densities. Consider that many native $P$. australis stands are typically quite small and are often found in close proximity to expansive monocultures formed by invasive $P$. australis. The susceptibility of the native $P$. australis genotypes to these herbivores may increase simply because they are proximal to a large reservoir of herbivores (i.e., associational susceptibility), or because as the quality of the invasive genotypes deteriorates (owing to extensive herbivore damage), the relative quality of the native genotypes improves (Barbosa et al. 2009). Spillover can also lead to apparent competition (i.e., indirect negative interactions between two species mediated through their shared herbivores; e.g. Holt and Lawton 1993). In an 
experimental study conducted in mixed-genotype marshes, Bhattarai (2015) found that native $P$. australis suffered increased herbivory in the presence of invasive $P$. australis, an indication that apparent competition occurs between native and invasive $P$. australis. Unless specificity is absolute, spillover of the biological control agent is almost certainly going to have negative consequences for the native $P$. australis.

3. Biogeographical considerations are important and necessary because of the broad North American distribution of native and invasive $P$. australis. Field surveys along a $19^{\circ}$ latitudinal transect indicated that damage and abundance of herbivores from several feeding guilds vary with latitude for native $P$. australis, suggesting that resistance to herbivores also varies with latitude (Cronin et al. 2015). Commongarden experiments further demonstrated that latitudinal variation in herbivore resistance in both native and invasive genotypes is genetically based and phenotypically plastic (Bhattarai 2015; Bhattarai et al. in review). What this means is that herbivore preference for and/or performance on invasive $P$. australis is likely to depend on the latitude of origin of the invasive plants and the environment within which the herbivores are released. For example, preference for invasive relative to native $P$. australis may be high if the release is conducted in the north but be low if it is conducted in the south. Consequently, spillover effects, associational susceptibility, and apparent competition may also vary with latitude (see Bhattarai 2015). These kinds of biogeographical considerations are rare for invasive plant management programs (Cronin et al. 2015). However, in the process of testing biological control agents, particularly for continent-wide invaders, pest managers should not ignore the possibility of geographic variation in the relative susceptibility of native plants to attack by that biological control agent.

Concerns about $P$. australis biological control were published as early as 2000 (Rooth and Windham 2000) and also addressed by Meyerson et al. (2009) and Cronin et al. (2015). Phragmites australis biological control is intended to address a major invasion in North America and is likely to change the ecology of vast areas of coastal and inland wetlands. However, the real risks to the native North American genotypes of $P$. australis (as indicated by recent research summarized above) may not have been fully considered, particularly the extirpation of native populations or the eventual extinction of the native North American lineage altogether. The concerns we raise need to be considered in the process of developing and approving the release of biological control agents and the entire approval process would benefit from greater transparency and wider input from Phragmites researchers globally.

Acknowledgments Support for the work described in this paper was provided by NSF Grant Numbers DEB 1050084 (to JTC) and 1049914 (to LAM), the Louisiana Environmental Education Commission (to GPB and WJA), and the University of Rhode Island Agricultural Experiment Station Grant Number RIO0H-332, 311000-6044 (to LAM). This paper is a Bard College Field Station-Hudsonia Contribution.

\section{References}

Allen WJ, Young RE, Bhattarai GP, Croy JR et al (2015) Multitrophic enemy escape of invasive Phragmites australis and its introduced herbivores in North America. Biol Inv. doi:10.1007/s10530-015-0968-2

Barbosa P, Hines J, Kaplan I et al (2009) Associational resistance and associational susceptibility: having right or wrong neighbors. Ann Rev Ecol Evol Syst 40:1-20

Bhattarai GP (2015) Biogeographical approaches for studying species invasion. Louisiana State University, Baton Rouge, Louisiana

Bhattarai GP, Meyerson LA, Anderson J, Cummings D, Allen WJ, Cronin JT (In review) Biogeography of a plant invasion: genetic variation and plasticity in latitudinal clines for traits related to herbivory. Ecol Monogr

Blossey B (2003) A framework for evaluating potential ecological effects of implementing biological control of Phragmites australis. Estuaries 26:607-617

Blossey B (2014) Identification, development, and release of insect biocontrol agents for the management of Phragmites australis. ERDC/EL CR-14-2. US Army Corps of Engineers, Washington DC. http://acwc.sdp.sirsi.net/client/ search/asset/1035680

Cronin JT, Bhattarai GP, Allen WJ, Meyerson LA (2015) Biogeography of a plant invasion: plant-herbivore interactions. Ecology 96:1115-1127

Floate KD, Whitham TG (1993) The hybrid bridge hypothesishost shifting via plant hybrid swarms. Am Nat 141:651-662

Graves SD, Shapiro AM (2003) Exotics as host plants of the California butterfly fauna. Biol Conserv 110:413-433

Häfliger P, Schwarzländer M, Blossey B (2005) Biology of Platycephala planifrons (Diptera: Chloropidae) and its potential effectiveness as biological control agent for invasive Phragmites australis in North America. Biol Control 34:302-311

Häfliger P, Schwarzländer M, Blossey B (2006) Impact of Archanara geminipuncta (Lepidoptera: Noctuidae) on aboveground biomass production of Phragmites australis. Biol Control 38:413-421

Hershner C, Havens KJ (2008) Managing invasive aquatic plants in a changing system: strategic consideration of ecosystem services. Conserv Biol 22(3):544-550 
Hinz HL, Häfliger P, Leiner R, Scott T, Soukou S (2014). Complete host testing with a potential biological control agent on common reed in view of submitting a petition for field release in winter 2014/15 (No. 1721-EN-01). CAB International, Delemont

Holt RD, Lawton JH (1993) Apparent competition and enemyfree space in insect host-parasitoid communities. Am Nat 142:623-645

Horner JD, Abrahamson WG (1992) Influence of plant genotype and environment on oviposition preference and offspring survival in a gallmaking herbivore. Oecologia 90:323-332

Hulme PE, Pyšek P, Jarošík V, Pergl J, Schaffner U, Vila M (2013) Bias and error in understanding plant invasion impacts. TREE 28:212-218

Jahner JP, Bonilla MM, Badik KJ et al (2011) Use of exotic hosts by Lepidoptera: widespread species colonize more novel hosts. Evolution 65:2719-2724

Kiviat E (2013) Ecosystem services of Phragmites in North America with emphasis on habitat functions. AoB Plants. doi:10.1093/aobpla/plt008

Kleine S, Müller C (2011) Intraspecific plant chemical diversity and its relation to herbivory. Oecologia 166:175-186

Lambert AM, Casagrande RA (2007) Susceptibility of native and non-native common reed to the non-native mealy plum aphid (Homoptera: Aphididae) in North America. Environ Entomol 36:451-457

Lambert AM, Winiarski K, Casagrande RA (2007) Distribution and impact of exotic gall flies (Lipara sp.) on native and exotic Phragmites australis. Aquat Bot 86:163-170

Lambertini C, Mendelssohn IA, Gustafsson MHG, Olesen B, Tenna RIIS et al (2012) Tracing the origin of Gulf Coast Phragmites (Poaceae): a story of long-distance dispersal and hybridization. Am J Bot 99:538-551

Meyerson LA (2000) Ecosystem-level effects of invasive species: a Phragmites case study in two freshwater tidal marsh ecosystems on the Connecticut river. Doctoral thesis, Yale University, New Haven

Meyerson LA, Chambers RM, Vogt KA (1999) The effects of Phragmites removal on nutrient pools in a freshwater tidal marsh ecosystem. Biol Inv 1:129-136

Meyerson LA, Saltonstall K, Windham L, Kiviat E, Findlay S (2000a) A comparison of Phragmites australis in freshwater and brackish marsh environments in North America. Wetl Ecol Manag 8:89-103
Meyerson LA, Vogt KA, Chambers RM (2000b) Linking the success of Phragmites australis to the decoupling of ecosystem nutrient cycles. In: Weinstein M, Kreeger D (eds) Concepts and controversies of tidal marsh ecology. Kluwer, pp 817-834

Meyerson LA, Saltonstall K, Chambers RM, Silliman BR, Bertness MD, Strong D (2009). Phragmites australis in eastern North America: a historical and ecological perspective. Human impacts on salt marshes: a global perspective. University of California Press, Berkeley, 57-82

Meyerson LA, Lambertini C, McCormick M, Whigham DF (2012) Hybridization of common reed in North America? The answer is blowing in the wind. AoB Plants. doi:10. 1093/aobpla/pls1022

Park MG, Blossey B (2008) Importance of plant traits and herbivory for invasiveness of Phragmites australis (Poaceae). Am J Bot 95(12):1557-1568

Paul J, Vachon N, Garroway CJ, Freeland JR (2010) Molecular data provide strong evidence of natural hybridization between native and introduced lineages of Phragmites australis in North America. Biol Inv 12(9):2967-2973

Pemberton RW (2000) Predictable risk to native plants in weed biological control. Oecologia 125:489-494

Rooth JE, Windham L (2000) Phragmites on death row: Is biocontrol really warranted? Wetl J 12:29-37

Saltonstall K, Peterson PM, Soreng RJ (2004) Recognition of Phragmites australis subsp. americanus (Poaceae: Arundinoideae) in North America: evidence from morphological and genetic analyses. SIDA 2004:683-692

Saltonstall K, Castillo HE, Blossey B (2014) Confirmed field hybridization of native and introduced Phragmites australis (Poaceae) in North America. Am J Bot 101:211-215

Schwarzländer M, Häfliger P (2000) Shoot flies, gall midges, and shoot and rhizome mining moths associated with common reed in Europe and their potential for biological control. In: Proceedings of the $\mathrm{X}$ international symposium on biological control of weeds, pp 397-420

Tewksbury L, Casagrande R, Blossey B, Häfliger P, Schwarzländer M (2002) Potential for biological control of Phragmites australis in North America. Biol Control 23(2):191-212

Underwood N, Rausher MD (2000) The effects of host-plant genotype on herbivore population dynamics. Ecology $81: 1565-1576$ 